The operator had a list of all the children to be screened in a session, and merely wrote " $R$ " or " $L$ " or both (indicating right or left eye) against the name of each child who failed to state correctly the number of blocks on the cards presented to him. If a child made only one mistake the card concerned was presented again at the end of the sequence, and if the number of blocks was then correctly stated it was not regarded as a failure. More than one mistake was considered to be a failure.

It is known that most children from the age of 4 years can count up to three. In order to be certain, this ability was checked for each of the children in the survey, but in any future use of the cards only those who failed the screening test would be checked.

\section{Results}

A total of 186 children aged $4 \frac{1}{2}$ to 7 years inclusive were screened both by a conventional method (the illiterate $\mathrm{E}$ or Sjögren's cards) and by the new method. A further 20 children passed the conventional test but were absent or had left the district before the new test was given. These children were not included in the analysis, but there is no reason to suppose that had they taken the new test the comparison of the results would have been materially altered. There were a further 12 children who were unable to co-operate with one or both tests, and they have also been omitted from the analysis.

The effectiveness of the new method was measured by comparing the results of the two tests. All the screening by the conventional methods was done in the ordinary way by health visitors or school nurses who were unaware that the children were to be screened again. All the screening by the new method was carried out by one of us (H. E.W.) and without any knowledge of the previous findings. The second screening was carried out within a few months of the first, and so it is unlikely that the visual acuity of any particular child would have materially changed in the interval.

There were 157 children who passed both the conventional and the new tests. A total of 29 failed one or both tests, and the Table shows a breakdown of these cases, with an indication of whether the subsequent referral to an ophthalmologist was considered by him to have been justified. In each case the ophthalmologist was unaware of the method which had been used to discover the defect. It will thus be seen that the new method detected every one of the justifiable referrals detected by the conventional methods (line 1). The new method also detected eight such referrals who had apparently been missed by the conventional methods (line 4).

\begin{tabular}{|c|c|c|c|c|}
\hline & \multicolumn{3}{|c|}{ Comparison of Methods in 29 Cases } & \multirow[b]{2}{*}{$\begin{array}{l}\text { Total } \\
\text { Cases }\end{array}$} \\
\hline & $\begin{array}{l}\text { Performance } \\
\text { with conven- } \\
\text { tional method }\end{array}$ & $\begin{array}{l}\text { Performance } \\
\text { with new } \\
\text { method }\end{array}$ & $\begin{array}{l}\text { Whether referral was } \\
\text { justifiable }\end{array}$ & \\
\hline$\frac{1}{2}$ & $\begin{array}{l}\text { Failed } \\
\text { Failed }\end{array}$ & $\begin{array}{l}\text { Failed } \\
\text { Failed }\end{array}$ & $\begin{array}{l}\text { Yes } \\
\text { Not known (child did not }\end{array}$ & 15 \\
\hline $\begin{array}{l}3 \\
4\end{array}$ & $\begin{array}{l}\text { Failed } \\
\text { Passed } \\
\text { Passed }\end{array}$ & $\begin{array}{l}\text { Passed } \\
\text { Failed } \\
\text { Failed }\end{array}$ & $\begin{array}{l}\text { No } \\
\text { Yes } \\
\text { Not known (children did }\end{array}$ & $\begin{array}{l}1 \\
2 \\
8\end{array}$ \\
\hline 6 & Passed & Failed & $\begin{array}{l}\text { not attend eye clinic) } \\
\text { No }\end{array}$ & 2 \\
\hline
\end{tabular}

\section{Advantages of New Method}

The principal advantages of the new method are as follows: (1) it appears to be at least as effective as existing methods for screening defects in visual acuity in young children; (2) only one operator is required ; (3) it can be used for illiterates without appearing to be a childish test ; (4) apart from being able to count up to three, no interpretation by the child is required; (5) each answer given by the child is definite and no interpretation by the cperator is required; (6) because the response is verbal there is no need constantly to watch each child, and so the new method is less tiring for the operator; and (7) the equipment is very cheap to produce.

The views expressed in this paper are entirely our own and do not necessarily represent the views of Staffordshire County Council. We wish to record our grateful thanks to Dr. G. Ramage, County Medical Officer of Health, for his encouragement and constructive criticisms ; to Mr. C. E. Dickenson and Mr. S. B. Billington, of the Staffordshire School Health Service, for their help in planning the project; and to the head teachers and staff in the schools for their interest and support.

\title{
Pregnancy and Untreated Addisonian Pernicious Anaemia
}

\author{
B. K. ARMSTRONG,* B.MED.SC. ; R. E. DAVIS,† F.I.M.L.T., F.I.S.T. ; J. D. MARTIN, $\ddagger$ M.D., F.R.c.o.g.
}

H. J. WOODLIFF, $§$ PH.D., M.R.C.P.ED.

Brit. med. F., 1968, 4, 158-159

\begin{abstract}
Cummary : The case histories are given of two patients, aged 38 and 35 years, who conceived while suffering from Addisonian pernicious anaemia. The relationship of these findings to the routine use of folic acid during pregnancy is discussed.
\end{abstract}

\section{Introduction}

Though the serum level of vitamin $B_{12}$ falls progressively throughout pregnancy (Martin et al., 1967 ; Whiteside et al.,

* Medical Student, University of Western Australia, Perth.
t Chief Technologist, Department of Haematology, Royal Perth Hospital.

pital.
$\ddagger$ Professor of Obstetrics and Gynaecology, University of Western Australia, Perth.

$\$$ Head of Department of Haematology, Royal Perth Hospital.
1968) and abnormally low levels are recorded in up to $40 \%$ of cases of megaloblastic anaemia in pregnancy (Benjamin et al., 1966), vitamin $B_{12}$ is said to have no place in the treatment of these cases and the serum vitamin $B_{12}$ levels return to normal with folic acid therapy (Giles, 1966).

Addisonian pernicious anaemia with vitamin- $B_{12}$ deficiency due to lack of intrinsic factor is exceedingly rare in pregnancy. Not one case was found among 30,000 pregnant women seen at a Liverpool hospital (Hibbard and Hibbard, 1968). Untreated Addisonian pernicious anaemia has been reported as a cause of infertility (Jackson et al., 1967) ; cases of megaloblastic anaemia have been described in infants breast-fed by mothers who had untreated Addisonian pernicious anaemia (Zuelzer and Rutzky, 1953 ; Lampkin et al., 1966); and cases of Addisonian pernicious anaemia diagnosed during pregnancy 
have been mentioned (Editor, 1960 ; Varadi, 1964 ; Fisher and Taylor, 1967), but we have been unable to find any reported cases. We therefore describe two cases, both of which have been briefly mentioned (Martin and Davis, 1964 ; Armstrong et al., 1967 ; Martin et al., 1967), which were found in a series of 827 serum vitamin $B_{12}$ assays performed on pregnant women (Martin et al., 1967).

\section{Case 1}

An Italian woman born in 1925 had had six abortions during the period 1948 to 1956 - two at 12 weeks' gestation and four at six weeks' gestation. She became pregnant again in 1959 and delivered at term a normal infant, the pregnancy being complicated by two small antepartum haemorrhages. Haemoglobin levels had remained low throughout the pregnancy-9.4 g. $/ 100 \mathrm{ml}$. at 28 weeks; $10.0 \mathrm{~g} . / 100 \mathrm{ml}$. at 38 weeks, and $10.6 \mathrm{~g} . / 100 \mathrm{ml}$. at term-in spite of iron therapy. The next pregnancy, in 1961, terminated with intrauterine death and spontaneous delivery at 32 weeks' gestation. In 1962 she had a further abortion at 16 weeks. Her haemoglobin then was 9.7 g./100 ml., haematocrit $32 \%$, M.C.H.C. $30 \%$, reticulocytes $1.9 \%$, and the blood film showed anisocytosis, poikilocytosis, and polychromasia. Three months later, in December 1962, her haemoglobin was 12.2 g. $/ 100 \mathrm{ml}$, haematocrit $37 \%$, M.C.H.C. $33 \%$, reticulocytes $2.9 \%$, and the blood film showed anisocytosis, poikilocytosis, and macrocytosis. She presented again with amenorrhoea of three months' duration in August 1963, when anaemia and splenomegaly were again noted. Her serum vitamin $\mathbf{B}_{12}$ level was $63 \mu \mu \mathrm{g} . / \mathrm{ml}$. and serum folate $20.3 \mathrm{~m} / \mathrm{g} . / \mathrm{ml}$. A barium-meal examination and gastric biopsy showed atrophic gastritis and an augmented histamine test meal showed achlorhydria. Her bone marrow was not examined.

After the administration of $0.6 \mu \mathrm{g}$. of ${ }^{58} \mathrm{Co}$-labelled vitamin $\mathrm{B}_{12}$, only $5.1 \%$ of the dose was recovered from the urine in 48 hours, indicating malabsorption (Stokes and Pitney, 1958). The addition of intrinsic factor to the dose increased the excretion to $31 \%$, thus establishing the diagnosis of Addisonian pernicious anaemia. During these tests the patient was in hospital and care was taken to ensure that the urine collections were complete. Haemoglobin electrophoresis showed that $5 \%$ of the total haemoglobin was $\mathbf{H b} \mathbf{A}_{2}$ (normal $<4 \%$ ) and a further diagnosis of $\beta$-thalassaemia minor was made. Her period of amenorrhoea ended in October 1963, when a dilatation and curettage produced fragments of degenerate decidua, degenerate placental tissue, and inflamed hyperplastic proliferative endometrium, confirming the coexistence of pregnancy and Addisonian pernicious anaemia. In spite of vitamin- $B_{12}$ therapy she has not conceived again.

The possibility that some of her abortions were due to foetal thalassaemia major has been considered, but attempts to study the father have been unsuccessful.

\section{Case 2}

An Italian woman born in 1930 had a normal pregnancy in 1962 and presented again, 21 . weeks pregnant, in October 1965; her haemoglobin was $10.0 \mathrm{~g}, / 100 \mathrm{ml}$. and she was given oral iron. At 26 weeks' gestation her haemoglobin was $11.5 \mathrm{~g} . / 100 \mathrm{ml}$, haematocrit $35 \%$, M.C.H.C. $33 \%$, and the blood film showed slight anisocytosis. Her bone marrow was not examined. She was given oral folic acid and ascorbic acid, and a month later the haemoglobin rose to $12.9 \mathrm{~g} .1100 \mathrm{ml}$. Serum taken at 26 weeks subsequently showed a vitamin $B_{12}$ level of $<40 \mu \mu \mathrm{g} . / \mathrm{ml}$. and a folate of $9.1 \mathrm{~m} \mu \mathrm{g} . / \mathrm{ml}$. Vitamin- $\mathrm{B}_{12}$ therapy was therefore started in February 1966 at 36 weeks' gestation. At 38 weeks the haemoglobin was $12.2 \mathrm{~g} . / 100 \mathrm{ml}$. and at term, when she was delivered of a normal infant, the haemoglobin was $13.5 \mathrm{~g}, / 100 \mathrm{ml}$. On cessation of lactation in October she was given $0.8 \mu \mathrm{g}$. of ${ }^{57} \mathrm{Co}$-labelled vitamin $\mathbf{B}_{12}$ orally, and the absorption was estimated by measurement of radioactivity in the plasma (Armstrong and Woodliff, 1966). There was $0.49 \%$ of the dose per litre of plasma, which is in the equivocal range between normal and malabsorption levels. This level was increased to normal-1.4\% of the dose per litre-by the addition of intrinsic factor to the dose, and repetition of the first test gave $0.28 \%$ of the dose per litre of plasma, which is in the malabsorption range. Serum taken at the same time as this test contained parietal cell antibody and a titre of intrinsic factor antibody equal to $44 \mathrm{~m} \mu \mathrm{g}$. units per ml., which is consistent with Addisonian pernicious anaemia (Ungar, 1967).

\section{Discussion}

We have reported on two patients found to have a low serum vitamin $B_{12}$ level in pregnancy in whom the diagnosis of Addisonian pernicious anaemia was established by modern techniques. The possibility of coexistence of pregnancy and vitamin- $B_{12}$ deficiency due to lack of intrinsic factor has therefore been demonstrated. It is of interest that both patients were Italian, and their ages, 38 and 35 years, fell toward the upper limit of the usual child-bearing age range. The five patients reported on by Jackson et al. (1967) as infertile owing to Addisonian pernicious anaemia were from 28 to 39 years old. Thus it is only in older women that pregnancy and Addisonian pernicious anaemia are likely to coincide.

The probability of precipitating the neurological complications of Addisonian pernicious anaemia by folic acid administration in pregnancy is small. Neurological signs did not appear in our second patient, who was treated initially with folic acid, and their occurrence during pregnancy does not seem to have been reported elsewhere. In view of these two cases, however, some caution is justified in the prophylactic use of folic acid during pregnancy, and physiological doses (300-500 $\mu \mathrm{g}$./day) rather than pharmacological doses are recommended. Where levels of $5 \mathrm{mg}$. of folic acid a day are required to replenish body stores in the treatment of pregnancy anaemias (Grossowicz et al., 1967) vitamin-B ${ }_{12}$ deficiency should be excluded by measurement of the serum level, particularly if the patient is over 30 .

We wish to thank Dr. Berta Ungar for performing the test for parietal cell and intrinsic factor antibody and Dr. A. F. Fleming for his helpful comments.

\section{REFERENCES}

Armstrong, B. K., Martin, J. D., Davis, R. E., and Woodliff, H. J. (1967). Brit. med. 7., 2, 312.

Armstrong, B. K., and Woodliff, H. J. (1966). Med. F. Aust., 1, 709. Benjamin, F., Bassen, F. A., and Meyer, L. M. (1966). Amer. F. Obstet. Gynec., 96, 310.

Fisher, J. M., and Taylor, K. B. (1967). Lancet, 1, 695.

Editor (1960). Obstet. Gynec. Surv., 15, 22.

Giles, C. (1966). F. clin. Path., 19, 1.

Grossowicz, N., Izak, G., and Rachmilewitz, M. (1967). Brit. med. f., 2, 574.

Hibbard, B. M., and Hibbard, E. D. (1968). Brit. med. Bull., 24, 10.

Jackson, I. M. D., Doig, W. B., and McDonald, G. (1967). Lancet, 2, 1159.

Lampkin, B. C., Shore, N. A., and Chadwick, D. (1966). New Engl. F. Med., 274, 1168 .

Martin, J. D., and Davis, R. E., (1964). F. Obstet. Gynaec. Brit. Cwlth, 71, 400.

Martin, J. D., Davis, R. E., and Stenhouse, N. (1967). F. Obstet. Gynaec. Brit. Cwlth, 74, 697.

Stokes, J. B. and Pitney, W. R. (1958). Brit. med. F., 1, 322.

Ungar, B. (1967). Aust. 7. exp. Biol. med. Sci., 45, 317.

Varadi, S. (1964). Lancet, 1, 1331.

Whiteside, M. G., Ungar, B., and Cowling, D. C. (1968). Med. F. Aust., 1,338 .

Zuelzer, W. W., and Rutzky, J. (1953). Advanc. Pediat., 6, 243. 